\title{
Pendekatan Realita Perkuliahan Pada Media Online
}

\section{Surya Eka Priyatna}

Fakultas Dakwah dan Komunikasi IAIN Antasari

\begin{abstract}
In fact, the conventional method is still widely used in the lecture. The lecture method is one of the most popular among lecturers. This method is still regarded as an effective method for delivery of material to the students. The development of online learning provide a positive contribution to the development of learning methods. To achieve optimal lecture, then searched the conventional lecture approach reality in online media
\end{abstract}

Keywords: lecture, conventional, applications, online media

Pada kenyataannya metode konvensional dalam perkuliahan masih sering digunakan. Metode ceramah merupakan salah satu yang paling populer di kalangan dosen. Metode ini masih dipandang sebagai metode yang efektif untuk penyampaian materi kepada mahasiswa. Berkembangnya pembelajaran online memberikan kontribusi yang positif pada perkembangan metode pembelajaran. Untuk mencapai tujuan perkuliahan yang optimal, maka dicari pendekatan realita perkuliahan konvensional pada media online

Kata kunci: kuliah, konvensional, aplikasi, media online

Perkuliahan konvensional biasanya menggunalkan metode ceramah dan tanya jawab, Ceramah digunakan dalam upaya dosen untuk menyampaikan materi melalui lisan kepada mahasiswa di dalam kelas. Metode ini biasanya dilanjutkan dengan pemberian tugas untuk mengetahui pemahaman mahasiswa.

\section{A. Kuliah Konvensional}

1. Metode Ceramah

Metode caramah sering kali memberikan porsi lebih banyak kepada dosen untuk menjelaskan materi, sebaliknya mahasiswa lebih banyak mendengarkan dan mengerjakan latihan dan soal apabila pada akhir sesi dosen menyediakan waktu untuk itu.

Dalam metode ceramah, dosen dapat dibantu dengan instrumen pendukung audio visual untuk penjelasan yang lebih detail dan mendalam.

a) Kelebihan Metode Ceramah

Metode ceramah mempunyai kelebihan yakni dosen mudah menguasai keberlangsungan kuliah, serta dapat diikuti oleh sejumlah besar mahasiswa. Hal lainnya adalah materi yang akan disampaikan dapat di siapkan sesuai rencana perkuliahan, ini akan berdampak penyampaian bisa terlaksana dengan baik.

b) Kekurangan Metode Ceramah

Adapun kekurangan metode ceramah adalah penjelasan dosen yang memakan waktu lama, sering kali menjadi membosankan. Karena jarang terjadi interaksi aktif, maka tidak ada tolok ukur bahwa materi ceramah yang disampaikan merupakan

Email penulis: suryaekapriyatna@gmail.com

Alhadharah Jurnal Ilmu Dakwah Vol. 15 No. 30, Juli-Desember 2016, 63-69 
hal yang menarik, dan menjadikan dosen tidak obyektif dalam menilai perkuliahan yang dilaksanakannya.

Berikutnya adalah jika dilakukuan terus menerus menjadikan mahasiswa terpola pasif dan hanya mendengarkan penjelasan dari dosen.

\section{Metode Tanya Jawab}

Metode tanya jawab merupakan kelanjutan dari metode ceramah. Hal ini disebabkan dosen mengharapkan materi yang disampaikan terserap dengan baik oleh para mahasiswa.

Metode tanya jawab mempunyai kelebihan-kelebihan untuk memberikan fokus pembahasan yang diharapkan kepada mahasiswa, mengembangkan kemampuan menganalisa dan memori. Tanya jawab juga dapat melatih keberanian mahasiswa untuk mengemukakan pendapat dan merangkai kata yang tepat untuk dimengerti orang banyak.

Namun, jika dosen gagal memotivasi mahasiswa untuk dapat berinteraksi dan aktif bertanya jawab, akan membuat waktu banyak terbuang. Tentunya ini akan membuat tidak efisien. Membuat pertanyaan pun harus melihat dari tingkat pemahaman mahasiswa dan materi yang telah disampaikan sebelumnya, ini merupakan kesulitan tersendiri bagi dosen.

Kesulitan lainnya adalah tentu tidak semua mahasiswa bisa seluruhnya dapat interaksi tanya jawab, apalagi jika jumlahnya cukup besar di kelas.

\section{Pendekatan Perkuliahan Konvensional}

Umumnya pendekatan metode konvensional dalam perkuliahan dilaksanakan dengan tujuan untuk menyampaikan konsep-konsep pemikiran dan bukan membahas mengenai kompetensi suatu keahlian tertentu. Dosen mendominasi sebagai yang menyampaikan materi dan mahasiswa berperan sebagai penerima materi, sehingga terkesan sebagai penyiaran materi kuliah.

Syarat yang harus dipenuhi untuk dapat memenuhi standar minimal terjadinya perkuliahan antara lain :

a) Dosen

Dosen merupakan seorang pengajar sekaligus pendidik. Mengapa demikian? dikarenakan selain menyapaikan materi sesuai yang telah dirancang sebelumnya, dosen juga mempunyai kewajiban untuk menuntun mahasiswa ke arah tingkah laku dan perkataan dan perbuatan yang lebih baik.

Sebagai pengajar, target utamanya adalah membuat mahasiswa memahami dan mengerti tentang materi yang diberikan. Kemudian sebagai pendidik, dosen bertanggung jawab atas semuailmu dari materi yang diajarkan untuk tidak menyimpang terhadap norma-norma etika moral dan kebudayaan yang berlaku dalam masyarakat setempat.

\section{b) Mahasiswa}

Mahasiswa adalah satu orang atau lebih yang menyiapkan diri untuk belajar, menyimak, mengamati, mengananalisa, dan mengaplikasikan materimateri perkuliahan. 
c) Materi Kuliah

Materi kuliah adalah hal utama yang harus ada dan merupakan esensi sistem perkuliahan. Materi kuliah sudah dirancang dengan Silabus, kemudian diturunkan melalui Rancangan

Acara Perkuliahan dan Jurnal perkuliahan. Pembahasan materi kuliah bersifat berkelanjutan antara satu sesi dengan sesi lainnya, sesuai dengan tujuan akhir dari pencapaian kompetensi yang diharapkan.

d) media

Media adalah alat dan bahan yang disiapkan, mempunyai spesifikasi tertentu sesuai dengan materi perkuliahan. Media belajar dewasa ini mengalami pengembangan yang signifikan melalui multi media, seperti : papan tulis, lcd proyektor, audio.

Secara umum media digunakan untuk membantu kegiatan perkuliahan. hal tersebut digunakan untuk merangsang daya fikir dan dan konsentrasi mahasiswa untuk lebih memperhatikan materi yang diberikan. Biasanya merupakan sarana fisik, namun sekarang sudah mulai bergeser ke digital.

Media mempunyai posisi yang sangat penting dalam proses perkuliahan. Jika tidak ada media sebagai jembatan pengetahuan dan pemahaman, maka proses komunikasi tidak akan berlangsung dengan baik serta tujuan perkuliahan tidak akan tercapai.

Ada beberapa jenis media yang bisa dipergunakan untuk perkuliahan, seperti media visual, berupa grafik, diagram, chart, bagan, poster, kartun, komik. Media audial berupa radio, tape recorder, laboratorium bahasa, dan sejenisnya. Projected still media seperti slide; over head projektor (OHP), in focus dan sejenisnya. Projected motion media yakni film, televisi, video (VCD, DVD, VTR), komputer dan sejenisnya.

Penggunaan media untuk perkuliahan dapat dioptimalkan tergantung dari isi materi,cara penjelasan dalam media dan karakteristik mahasiswa.

Tujuan diadakannya media pembelajaran dalam rangka mempermudah dan meningkatkan efisiensi proses perkuliahan, menjaga relevansi dengan tujuan perkuliahan serta membantu konsentrasi mahasiswa.

e) komunikasi

Komunikasi adalah kegiatan terpenting sebagai jembatan antara mahasiswa, dosen dan materi pembelajaran. komunikasi terdiri atas sifat komunikasi, dan perangkat komunikasi. Sifat komunikasi terbagi atas dua elemen, yakni komunikasi satu arah dan komunikasi dua arah. Komunikasi satu arah bersifat informatif, mengandung pernyataan dan penjelasan secara keseluruhan, umum, dalam artian dapat di tangkap pengertiannya oleh sebagian besar atau seluruh pembelajar. Contoh : Ceramah, melihat video, mendengarkan audio.

Komunikasi dua arah merupakan pendalaman dari informasi yang diberikan, bisa berupa diskusi dan kerja kelompok. Dalam kegiatan perkuliahan, komunikasi berfungsi sebagai pengendali proses prilaku mahasiswa, baik itu 
berupa perintah mengerjakan tugas ataupun panduan formal tata cara perkuliahan.

Komunikasi juga dapat digunakan untuk memotivasi mahasiswa melalui penjelasan tentang apa yang harus dilakukan dalam memahami dan menganalisa materi perkuliahan.

Dalam hal lain komunikasi juga diperlukan untuk pengungkapan sosial emosional dalam interaksi kepada dosen atau antar mahasiswa. Yang terpenting adalah penyampaian informasi yang berkaitan dengan penjelasan materi, datadata yang terkait sebagai dasar dalam pengambilan keputusan dalam setiap jawaban ataupun argumen dari mahasiswa.

\section{B. Media Online}

Batasan penyebutan media online disini adalah segala media yang dapat dihubungkan melalui jaringan internet.

Sekarang banyak sekali website yang berstruktur untuk pendidikan dan pembelajaran jarak jauh, contohnya Moodle. Moodle biasa di sebut juga dengan $e-$ learning yaitu electronic learning, dimaksudkan adalah suatu perangkat lunak media belajar yang terhubung dengan internet.

1. Moodle

Moodle merupakan e-learning populer dengan fitur-fitur yang dapat digunakan untuk terselenggaranya acara perkuliahan. Terdapat beberapa macam fitur antara lain :

1. berinteraksi melalui chat

2. upload dan download tugas atau bacaan

3. memberikan penugasan berjangka waktu

4. menguji mahasiswa secara online melalui soal pilihan ganda atau essay

5. memberikan kuliah melalui video dan audio

Dari banyak fungsi dan kelebihan-kelebihan fitur diatas ada satu kekurangan Moodle, yaitu konferensi video live, untuk memenuhi keperluan perkuliahan konvensional, yang walaupun metode klasik, tetapi masih cukup efektif untuk memberikan pengertian dan pemahaman yang menyeluruh bagi mahasiswa.

Kekurangan ini dapat ditutupi oleh sebuah aplikasi media sosial online Bigo Live.

\section{Bigo Live}

Bigo Live sejatinya adalah aplikasi yang dipakai di smartphone berbasis android dan iphone. Tujuan awal dari aplikasi ini dipakai untuk berbagi trend fashion terbaru.

Aplikasi ini dapat menyiarkan acara secara langsung dan dapat ditonton oleh masyarakat yang menggunakan Bigo Live. Bigo Live mempunyai fitur yang jarang ada di aplikasi lain yaitu fitur bayaran.

Sistemnya adalah mengumpulkan banyak tanggapan positif dari penonton melalui semacam pemberian tanda "suka" pada pembuat acara. Sejumlah tanda "suka" yang terkumpul akan bisa ditukarkan dengan uang. Penghargaan juga dapat diperoleh terhadap pembuat acara dengan penonton yang berjumlah banyak. 
Pendekatan

Surya

Hal ini yang mengakibatkan Bigo Live sering sekali menjadi ajang penyalahgunaan bagi pembuat acara yang tidak bertanggung jawab, yang sematamata menginginkan pendapatan tanpa melihat etika kesopanan. Namun ini sudah diatas dengan pertaturan baru dari pihak Bigo Live untuk menjaga dari kontenkonten pornografy dan kekerasan.

Kelebihan fitur-fitur Bigo Live :

1. Aplikasi penyiaran video streamming gratis

2. Gambar dan audio jernih, sesuai dengan perangkat yang digunakan

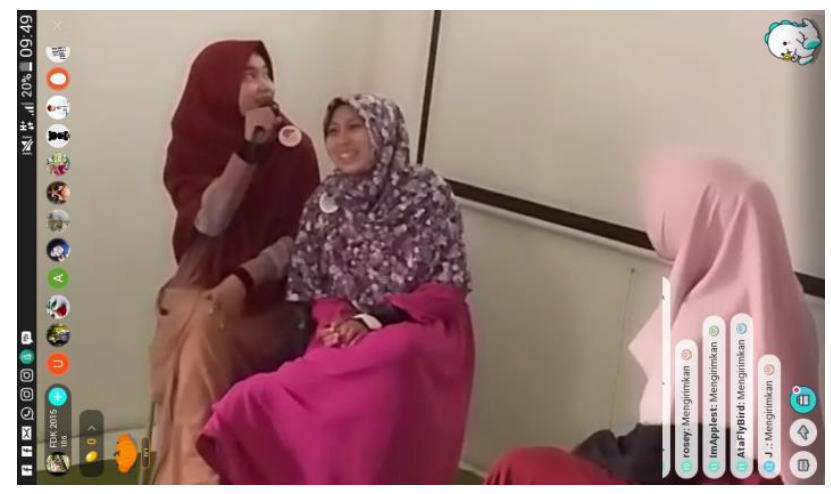

Gambar 1 : Mahasiswa FDK Presentasi di Bigo Live

3. dengan jaringan internet yang stabil, maka live streaming tidak akan terputusputus, selayaknya siaran televisi di smartphone.

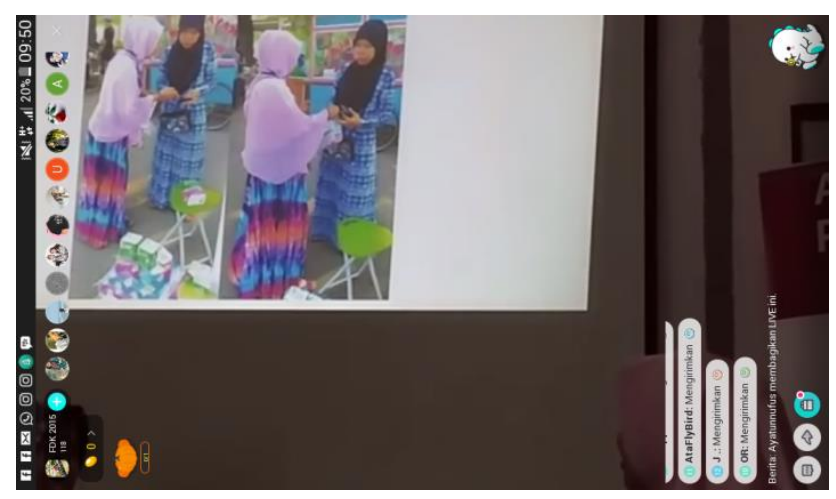

Gambar 2 : LCD Proyektor telihat jelas dan jernih

4. penonton dapat diihat secara nyata jumlahnya 


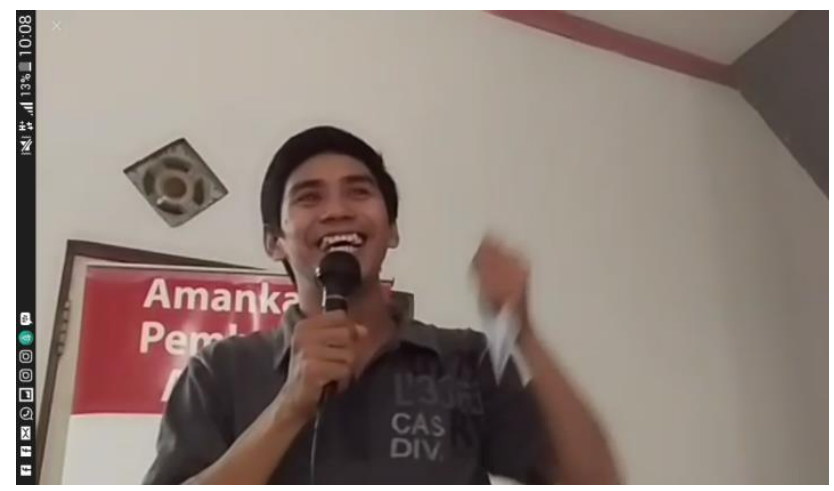

(Gambar 3 : Suara terdengar jelas dan jernih)

5. dapat berinteraksi melalui chat dan video call

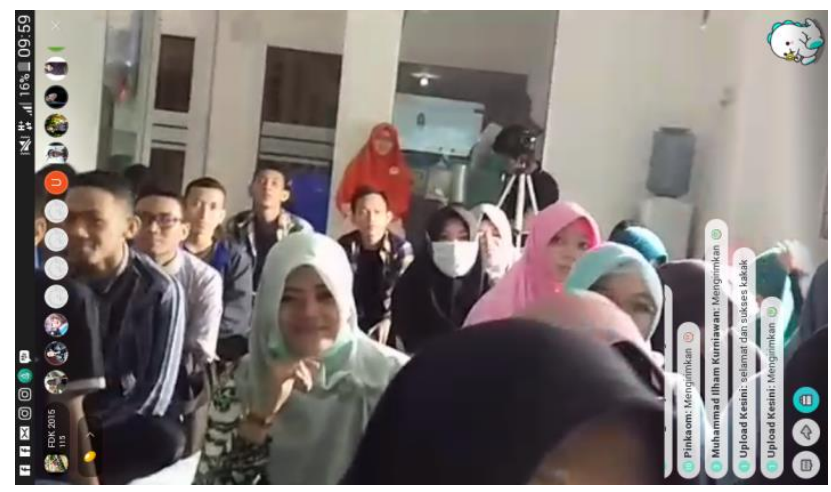

(Gambar 4 : video stramming dapat menjangkau area yang luas)

6. mendapatkan penghargaan berupa uang apabila acara tersebut diminati banyak pengguna Bigo Live

Dengan kelebihan fitur Bigo Live diatas, maka kekurangan pada Moodle dapat diatasi oleh Bigo Live. Dengan penggabungan dua aplikasi berbasis internet ini maka pendekatan realita perkuliahan pada media online dapat terlaksana dengan baik.

\section{Diskusi dan Kesimpulan}

Perkuliahan konvensional dengan metode ceramah dan tanya jawab masih efektif untuk diselenggarakan. Dengan berkembangnya pembelajaran online maka dicari aplikasi yang tepat untuk dapat mengakomodir keperluan perkuliahan konvensional tersebut. Sejauh ini aplikasi berbasis web e-learning Moodle dan Bigo Live dapat menjembatani keperluan tersebut.

\section{Referensi}

Bc. Viera Boumová, 2008. Traditional vs. Modern Teaching Methods: Advantages and Disadvantages of Each Master's Diploma Thesis. Masaryk University Faculty of Arts Department of English and American Studies. English Language and Literature

Anna Ya Ni, 2000. Comparing the Effectiveness of Classroom and Online Learning: Teaching Research Methods. California State University-San Bernardino 
Yap Wei Li, 2016. Transforming Conventional Teaching Classroom to Learner-Centred Teaching Classroom Using Multimedia-Mediated Learning Module. International Journal of Information and Education Technology, Vol. 6, No. 2, February

Belias Dimitrios, PhD Candidate, 2013. Traditional Teaching Methods Vs. Teaching Through The Application Of Information And Communication Technologies In The Accounting Field: Quo Vadis?. European Scientific Journal edition vol.9 October

Michael J. Prince, 2006. Inductive Teaching And Learning Methods: Definitions, Comparisons, And Research Bases. Bucknell University

Čonková Monika, 2013. Analysis of Perceptions of Conventional and E-Learning Education in Corporate Training. Journal of Competitiveness. Vol. 5, Issue 4, pp. 73-97, December

Mahendrenath Motah, 2007. Learning, Types of Learning, Traditional Learning Styles and the Impact of E-Learning on the Performance of Secondary School Students: The Perception of Teachers. Proceedings of the 2007 Computer Science and IT Education Conference

Daniel Trottier and Christian Fuchs, 2010. Theorising Social Media, Politics and the State An Introduction. Parliament Of Canada

Andrew Perrin, 2015. Social Networking Usage: 2005-2015. Pew Research Center. October 